\title{
UPAYA LEMBAGA PENDIDIKAN ISLAM DALAM MENANGKAL RADIKALISME
}

\author{
Oleh \\ Heri Cahyono \& Arief Rifkiawan Hamzah \\ Univeritas Muhammadiyah Metro, UIN Sunan Kalijaga Yogyakarta \\ hericahyono808@gmail.com, ariefrifkiawan@gmail.com
}

\begin{abstract}
This paper aims to reveal and explain the factors of entry and development of radicalism in Islamic educational institutions. Then explain about the antiradiklalisme Islam education in preventing and tackling radicalism in Islamic educational institutions. Islamic educational institutions in this contemporary era need to get more attention from academics and education practitioners, because Islamic educational institutions are vulnerable to the entry of radical ideas. These ideas are spread by various groups who simultaneously embrace radicalism in Indonesia. On the other hand, Islamic educational institutions are not yet fully prepared and pay attention to the symptoms of radicalism that seek to enter into it. The Islamic educational institution is still focused on its internal, and has not fully responded to the symptoms of radicalism in Indonesia. This paper is focused on Islamic educational institutions, because the concrete form of the implementation of Islamic education is in the institution. Islamic educational institutions have a strong potential to ward off radicalism so as not to freely enter and poison educators and learners. Islamic education institutions in this case need to respond seriously, namely by growing awareness about the existence of radicalism. This awareness will lead to massive movements. Departing from awareness, Islamic education institutions should implement and optimize the management of Islamic education continuously, then apply Islamic education with multicultural, tolerant, and moderate. With this, all educators and learners in educational institutions can have a broad and respectful view, and avoid radicalism.
\end{abstract}

\section{Keyword: Islamic Educational Institutions, Radicalism, Multikultural}

\begin{abstract}
Abstrak
Tulisan ini bertujuan untuk mengungkap serta menjelaskan faktor-fakor masuk dan berkembangnya radikalisme di lembaga pendidikan Islam. Kemudian menjelaskan mengenai pendidikan Islam anti radiklalisme dalam mencegah dan menanggulangi radikalisme di lembaga pendidikan Islam. Lembaga pendidikan Islam di era kontemporer ini perlu mendapatkan perhatian yang lebih dari para akademisi dan praktisi pendidikan, karena lembaga pendidikan Islam rentan dimasuki oleh pahampaham radikal. Paham-paham ini disebarkan oleh berbagai golongan yang secara
\end{abstract}


bersamaan menganut paham radikal di Indonesia. Di sisi lain, lembaga pendidikan Islam belum sepenuhnya siap dan memperhatikan adanya gejala radikalisme yang berusaha masuk ke dalamnya. Lembaga pendidikan Islam masih fokus terhadap internalnya, dan belum sepenuhnya merespon gejala-gejala radikalisme di Indonesia. Tulisan ini difokuskan pada lembaga pendidikan Islam, karena wujud konkrit dari pelaksanaan pendidikan Islam ada pada lembaganya. Lembaga pendidikan Islam memiliki potensi yang kuat untuk menangkal radikalisme agar tidak secara leluasa masuk dan meracuni pendidik dan peserta didik. Lembaga pendidikan Islam dalam hal ini perlu untuk merespon dengan serius, yaitu dengan menumbuhkan kesadaran mengenai adanya radikalisme. Kesadaran ini akan membuahkan gerakan-gerakan yang masif. Berangkat dari kesadaran, lembaga pendidikan Islam harus menerapkan dan mengoptimalkan manajemen pendidikan Islam secara kontinyu, kemudian menerapkan pendidikan Islam berwawasan multikultural, toleran, dan moderat. Dengan hal tersebut, seluruh pendidik dan peserta didik di lembaga pendidikan dapat berpandangan yang luas dan selalu menghargai, serta terhindar dari paham-paham radikal.

\section{Kata Kunci: Lembaga Pendidikan Islam, Radikalisme, Muktikultural}

\section{A. PENDAHULUAN}

\section{Latarbelakang Masalah}

Dunia pendidikan formal di Indonesia, kini sangat rawan disusupi oleh radikalisme. ${ }^{1} \mathrm{Hal}$ tersebut menjadi perhatian yang serius dalam seminar di Yogyakarta. Ahmad Syafii Maarif yang hadir sebagai pembicara menyinggung bahwa radikalisme telah masuk pada lembaga pendidikan, dengan indikator para dosen dan gurunya ada yang mengajarkan radikalisme. ${ }^{2}$ Sifat pendidikan yang terbuka dan

\footnotetext{
${ }^{1}$ http://news.metrotvnews.com/peristiwa/4 KZEoWpk-dunia-pendidikan-dinilai-rawandisusupi-paham-radikalisme

${ }^{2}$ Seminar bertema "Bisikan dari Jogja: Refleksi dan Evaluasi Bidang Kebudayaan Tiga Tahun Pemerintahan Jokoqi-JK" pada 21-22 Oktober 2017. https://nasional.tempo.co/read/1026907/3-tahunjokowi-jk-akademikus-soroti-menguatnyaradikalisme
}

demokratis, ${ }^{3}$ memberikan ruang bagi gerakan radikal untuk menyusupkan pemahamannya.Bahkandalam lembagalembaga pendidikan Islam tertentu, infiltrasi radikalisme sudah semakin nyata, hingga lembaga ini rela mengimplementasikankegiatan-kegiatan yang mengekspresikan dari pemahaman

${ }^{3}$ Diketahui bersama bahwa manusia hidup di dunia tidak bisa hidup sendiri tanpa ada oknum lain yang mendampinginya, begitu juga sebuah ilmu pengetahuan, bagaimana bisa berkembang sedangkan dia menutup diri dari hal-hal di selain dirinya. Oleh karena itu di dalam Islam, manusia diajarkan tentang hubungan vertikal dengan Tuhan, hubungan horizontal dengan manusia dan alam. Sikap keterbukaan ajaran Islam memberikan keleluasaan untuk melakukan hubungan ke seluruh penjuru dunia, baik dalam mengembangkan ilmu pengetahuan atau sekedar berkunjung untuk berbincang-bincang.Abuddin Nata, Filsafat Pendidikan Islam, (Jakarta: Gaya Media Pratama, 2005), hlm. 46. 
radikal.Lembaga pendidikan Islam tersebut tidak sadar bahwa dirinya sedang dimanfaatkan oleh gerakan radikal untuk menyebarkan pemahamannya kepada para peserta didik.Lambat laun, pemahaman radikal bisa tumbuh subur di lembaga pendidikan Islam, tanpa ada yang menyadari tentang bahayanya pemahaman ini bagi guru dan peserta didik.

Keterbukaan lembaga pendidikan Islam ini sejatinya sudah tepat, namun kekurangannya ialah belum ada kontrol yang kuat dari pengelola lembaga pendidikan. Kontrol ideologi dan kontrol teori yang seharusnya menjadi fokus, pada kenyataannya masih ada lembagalembaga pendidikan Islam yang kecolongan.Terbukanya ruang yang lebar dalam lembaga pendidikan Islam tanpa diiringi dengan kontrol yang kuat, akan sangat membahayakan bagi masa depan lembaga pendidikan. Lemahnya kontrol ini, bukan saja membahayakan lembaga pendidikan Islam, tetapi juga masyarakat sekitar, terutama para wali peserta didik.Mereka yang semula aman dan tidak terpengaruh radikalisme, dikhawatirkan menjadi kelompok yang radikal.

Hal yang sangat menghawatirkan adalah ketika lembaga pendidikan Islamdigadang-gadang menjadi agen dalam menangkal radikalisme, justru bisa berpotensi menjadi lembaga yang melestarikan ajaran radikal.Hal ini bisa terjadi jika pendidikan agama yang dijadikan sebagai sumber nilai yang moderat belum mewarnai atmosfir akademik di lembaga pendidikan Islam. Begitu juga dengan ideologi Pancasila, UUD 1945, dan Bhinneka Tunggal Ika,jika tidak mewarnai secara akademis dan praktis, gempuran radikalisme di lembaga pendidikan Islam akan terus menjalar dan berpotensi mengakar.

Potensi berkembangnya radikalisme dalam lembaga pendidikan, diungkapkan oleh Suhardi Alius sebagai kepala BNPT, iamenjelaskan bahwa kini tidak ada sesuatu yang benar-benar suci dari radikalisme, termasuk pendidikan.Lembaga pendidikan saat ini sungguh menghawatirkan,karena sudah terinfiltrasi radikalisme, baik radikal kanan maupun radikal kiri. Adanya infiltrasi ini ditunjukkan dengan hasil penelitian yang menjelaskan bahwa orang-orang yang berpaham radikal ratarata orang yang mampu dalam hal finansial, berpendidikan tinggi, dan bahkan ada yang sudah bergelar doktor. ${ }^{4}$

Di sisi lain, gerakan radikal yang sangat intens, akan memanfaatkan ruang yang terbuka dan kurangnya kontrol tersebut untuk menebarkan pemahamannya dengan berbagai macam cara.Menurut Irfan Amalee sebagai Direktur Peace Generation, indoktrinasi paham radikal dilakukan melalui beberapa narasi, yaitupertama narasi politik yang ditampilkan dalam bingkai ketidakadilan, dan memprovokasi untuk melakukan jihad dalam artian

\footnotetext{
${ }^{4}$ http://news.metrotvnews.com/hukum/Dk q62EeK-bnpt-riset-radikalisme-di-duniapendidikan
} 
perang.Kedua, narasi historis,pendidikan sejarah yang sejatinya dijadikan untuk menumbuhkan wisdom, justru menumbuhkan dendam.Ketiga, narasi psikologis, dengan menjadikan tokohtokoh kekerasan sebagai pahlawan yang harus diteladani. Keempat, kekerasan dianggap sebagai solusi dalam menyelesaikan problem ketidakadilan, ketimpangan, dan lain sebagainya.Kelima, narasi keagamaan dengan mengeksploitasi ayat-ayat alQur'an dan ditafsirkan secara eksklusif. ${ }^{5}$

$$
\text { Radikalisasi tersebut dapat }
$$
diimplementasikan melalui guru sendiri, kurikulum, buku ajar, atmosfir lingkungan pendidikan,dan pergaulan sehari-hari. Oleh karena itu, dunia pendidikan Islam saat ini harus responsif terhadap gejala-gejala radikalisasi di dunia pendidikan Islam. Responsif di sini diartikan bahwa lembaga pendidikan harus secepatnya menyadari sekaligus mencegah dan menanggulangi radikalisasi di dunia pendidikan Islam.Kesadaran lembaga pendidikan mengenai bahayanya radikalisme agama, akan memunculkan gerakan-gerakan yang menolak perkembangan radikalisme di lembaga pendidikan Islam, baik PAUD, MI, MTs, MA, MAK, hingga perguruan tinggi.

Pencegahan radikalisme di lembaga pendidikan Islam ini perlu perhatian yang khusus, karena mencegah radikalisme memerlukan berbagai

${ }^{5} \mathrm{http}: / /$ nasional.kompas.com/read/2017/05 /02/15444221/radikalisme.menyusup.ke.dunia.pe ndidikan.ini.lima.modusnya. disiplin ilmu pengetahuan, agama, dan gerakan. Menurut Mukhammad Ilyasin sebagai rektor IAIN Samarinda menyatakan bahwa untuk mencegah gerakan radikalisme ada tiga cara, yaitu selektif dalam merekrut tenaga pendidik, kurikulum berwawasan multikultural, penguatan organisasi kemahasiswaan, dan kesadaran berbasis keteladanan. ${ }^{6}$ Ketiga cara tersebut merupakan bagian dari sistem pendidikan Islam lainnya, yang juga membutuhkan perhatian dan readesain serta reaktualisasi.

Pendidikan Islam yang dijadikan sebagai sarana pewarisan tradisi para pendahulu kepada generasi di zaman sekarang, masih sangat penting dan relevan untuk diteliti mengenai bagaimana konsep dalam mencegah dan menanggulangi radikalisme di lembaga.Pendidikan Islam dalam perspektif sejarah, mencegah radikalisme dengan menerapkan pembelajaran yang inklusif dan toleran. Jika terdapat perbedaan antar sahabat, maka hal tersebut tidak lantas membuat para sahabat saling bermusuhan dan bertindak radikal.Dalam perkembangannya, imam madzhab yang notabene masih memiliki ikatan guru dan murid, mereka berbeda pendapat dan tetap saling menghormati.

Melalui tulisan ini, pendidikan Islam berusaha penulis jelaskan dengan

\begin{tabular}{l}
\hline $6 \mathrm{http} / / /$ www.iain- \\
samarinda.ac.id/index.php/2017/09/15/rektor- \\
iain-samarinda-paparkan-pola-pendidikan-anti- \\
radikalisme-di-seminar-internasional/
\end{tabular}


komprehensif mengenai sifat-sifat pendidikan Islam yang moderat, toleran, dan terbuka dalam mencegah radikalisme.Ciri khas pendidikan Islam tersebut saat ini perlu dikembangkan dalam konteks yang lebih luas dalam berbagai komponen pendidikan Islam, dengan tujuan untuk memperkaya kemoderatan pendidikan Islam di Indonesia.

\section{Rumusan Masalah}

a. Mengapa radikalismeberpotensi berkembang dilembaga pendidikan Islam?

b. Bagaimana gerakan lembaga pendidikan Islam dalam mencegah dan menanggulangi radikalisme?

\section{Tujuan dan Manfaat}

Tujuan dari penulisan artikel ini ialah untuk menjelaskan mengenai:

1. Faktor-faktor yang memberikan peluang bagiberkembangnya radikalisme di lembaga pendidikan Islam.

2. Gerakanlembaga pendidikan Islam dalam mencegah dan menanggulangi radikalisme.

Sedangkan manfaat dari penelitian ini sebagai berikut:

1. Manfaat secara teoretis dapat berkontribusi dalam mengembangkan dan menebarkan gagasan-gagasan pencegahan radikalisme di dunia pendidikan Islam.

2. Manfaat secara praktis dapat melaksanakan gagasan pendidikan
Islam anti radikalisme di lembagalembaga pendidikan Islam.

\section{B. RADIKALISME DI LEMBAGA PENDIDIKAN ISLAM}

Radikalisme merupakan suatu paham yang menginginkan adanya perubahan, pergantian, dan perbaikan dalam sistem sosial yang telah ada di masyarakat sampai akarnya.Paham radikal sangat mengehendaki adanya perubahan secara total, diganti dengan sistem yang menurutnya ideal, jauh lebih baik serta memberikan keadilan dan kemaslahatan. Cara-cara yang digunakan dalam merubah sistem seringkali menghalalkan kekerasan, hingga banyak yang menjadi korban dari misi kelompok radikal, sekalipun orang-orang yang tidak bersalah. ${ }^{7}$

Paham yang demikian disebarkan melalui berbagai macam media dan lembaga, termasuk di dalamnya pendidikan Islam.Sasaran radikalisasi mereka adalah para remaja dan pemuda yang masih berada di bangku sekolah.Analisis psikologis yang mereka lakukan menganggap bahwa remaja dan pemuda masih dalam kondisi labil dan mudah diprovokasi dengan hal-hal yang negatif.Tidak hanya itu, pendidikan Islam secara sistem juga menjadi sasaran radikalisasi, karena hal ini lebih menjanjikan untuk indoktrinasi pemahaman mereka. Oleh karena itu, para pengelola perlu memahami faktor-

${ }^{7}$ Zuly Qodir, Radikalisme Agama di Indonesia, (Yogyakarta: Pustaka Pelajar, 2014), hlm. 116 
faktor yang menyebabkan radikalisme menginfiltrasi lembaga penidikan Islam. Adapun faktor-faktor yang perlu diperhatikan dalam hal ini ialah:

\section{Faktor Internal Pendidikan Islam}

Faktor internal ini merupakan penyebab yang muncul dari dalam lembaga pendidikan Islam sendiri, yang berupa sifat dan sikap.Lembaga pendidikan Islam yang menjadi titik pusat proses pembelajaran, dilaksanakan dengan menjalankan semua komponen pendidikan Islam secara serasi, mulai dari dasar pendidikan Islam, tujuan, pendidik, peserta didik, kurikulum, metode, lingkungan,sarana-prasarana, dan pembiayaan. Namun ketika satu di antara komponen-komponen tersebut tidak berfungsi dengan baik, maka stabilitas pendidikan Islam menjadi terganggu. Faktor-faktor internal yang memberikan ruang masuknya radikalisme ialah:

\section{Kompetensi Sumber Daya Manusia yang Belum Maksimal}

Sumber daya manusia yang dimaksudkan di sini ialah pendidik pada lembaga pendidikan Islam.Pendidik pada lembaga pendidikan Islam tidak semua benar-benar memahami agama Islamdan ilmu pendidikan Islam secara mendalam. Pendidik tesebut hanya fokus terhadap konsentrasi yang ditekuninya sejak berada di bangku kuliah, dan cenderung belum merelevansikan antara ajaran Islam dengan bidang yang ditekuninya. Bahkan, hal-hal prinsip yang seharusnya dipahami oleh pendidik, pada kenyataannya masih banyak yang belum menyentuhnya.

Selain itu, pendidik di lembaga pendidikan Islam masih belum maksimal dalam memahami dan mempraktikkan ilmu pendidikan Islam. Ilmu pokok yang seharusnya dikuasai oleh pendidik tersebut pada kenyataannya masih belum banyak menyentuhnya. Sekalipun ada yang mempelajarinya di bangku perkuliahan, tidak semua pendidik jurusan pendidikan ini menyeriusi bidangnya. Ilmu pendidikan Islam dianggap tidak terlalu urgen dalam dunia pendidikan, baik secara teori maupun praktik. Secara teori,pemahaman pendidik mengenai ilmu pendidikan Islam masih minim, maka tidak heran dalam menjalankan proses pendidikan masih belum maksimal.

Ilmu pendidikan Islam seolah hanya diwajibkan bagi mereka para pendidik yang mengambil jurusan pendidikan, sedangkan bagi yang lain seolah tidak ada kaitannya. Maka tidak heran jika pendidik tidak terlalu memahami peluang dan tantanganlembaga pendidikan di masa sekarang dan masa depan.Bahkan, tantangan radikalisme yang dipandang bahaya, ternyata masih belum terlalu diperhatikan.Oleh karena itu, kompetensi yang seharusnya dimiliki oleh pendidik, kini perlu dikembangkan kembali dalam kaitannya dengan pengembangan sumber daya manusia.

Maka benar apa yang dikatakan oleh Yeni Wahid yang mengatakan bahwa "Banyak guru agama yang 
kualitasnya belum memenuhi standar, sehingga tidak dapat membendung masuknya paham radikal" "Hal tersebut bukan saja khusus bagi pendidik agama Islam, tetapi juga sebenarnya persoalan kualitas dan beban dalam membendung masuknya paham radikal berada di pundak pendidik lain.Membendung masuknya radikalisme merupakan tanggung jawab bersama seluruh sumber daya manusia yang ada di lembaga pendidikan Islam.

\section{Kurangnya Motivasi Mengembangkan Kompetensi}

Perlunya mengupgrade ilmu pengetahuan bagi pendidik merupakan rutinitas yang harus dilakukan di setiap waktu.Namun pada kenyataannya, banyak pendidik-pendidik yang belum mengepgrade dan mengembangakan pemahamannya mengenai bidang yang ditekuninya. Ilmu yang dulu di dapatkan, tidak lagi dikembangkan. Makareorientasi pendidikan dan pembelajaran, hanya menjadi wacana yang tidak membumi, sehingga lembaga pendidikan Islam menjadibelum responsif terhadap isu-isu terbaru dalam dunia pendidikan Islam.

Pendidik hanya disibukkan dengan urusan administrasi dan pribadiyang banyak menguras waktu dan tenaga. Urusan pengembangan diri dan inovasipembelajaran menjadi sektor yang tidak terlalu dinomorsatukan dalam kesehariannya.Kemampuan diri

\footnotetext{
${ }^{8}$ https://nasional.tempo.co/read/847299/w ahid-foundation-lebih-60-persen-aktivis-rohissiap-jihad
}

dianggapnya sudah final, karena sudah mendapatkan posisi yang bagus dan bisa mengangkat strata sosial. Derajat sosial yang sudah terangkat juga mempengaruhi ketidakminatan pendidik dalampengembangan pengetahuannya di masa kini. Merasa nyaman dengan posisinya, membuatnya tidak lagi merasakan ancaman dan tantangan yang dapat menurunkan strata sosialnya.

\section{Kontrol yang Belum Maksimal}

Kedua hal di atas bisa terjadi karena aktivitas pendidik kurang dikontrol oleh pendidik lainnya, terutama oleh kepala sekolah dan pengawas.Kontrol adalah salah satu dari fungsi manajemen pendidikan untuk mengedalikan arah pendidik dalam melaksanakan tugasnya. Kurangnya kontrol dapat membahayakan pendidik, pasalnya dengan keterbatasan pemahaman agama Islam dan ilmu pendidikan Islam, ia dapat terpengaruh dengan paham-paham radikal yang didapatkannya melalui media sosial maupun buku-buku yang ketat.Kemudian tanpa menelusuri sumber dan membandingkan dengan buku-buku keislaman lainnya, pemahaman parsial tersebut disampaikan dalam pembelajaran di kelas pada peserta didik.

Selain itu, ada pendidik dalam melaksanakan tugasnya terkesan mengabaikan aktivitas peserta didik di lingkungan pendidikan maupun di luar pendidikan. Mengabaikan artinya tidak mengontrol setiap aktivitas peserta didik, sehingga apapun aktivitas peserta didik 
tidak diketahui oleh pendidik. Hal ini ditunjukkan dalam setiap kegiatan pembelajaran di kelas, pendidik hampir tidak menanyakan aktivitas peserta didik di sekolah dan di luar sekolah.Kebanyakan pendidik ketika memasuki kelas ataupun di luar kelas hanya membahasmata pembelajaran yang telah lalu maupun yang akan datang, tanpa diiringi identifikasi peserta didik.

Implikasi dari kurangnya kontrol ini, memberikan jalan bagi buku-buku yang ketat dan disisipi paham radikal untuk masuk ke lembaga pendidikan Islam. Ironisnya, buku-buku tersebut tidak ditelaah terlebih dulu, sehingga secara mudah dijadikan bahan ajar dalam pembelajaran. Buku-buku yang masuk ke lembaga pendidikan Islam tidak terlebih dulu dibedah dan didiskusikan kontennya oleh seluruh pendidik. Pendidik menerima jadi dan membacanya tatkala hendak mengajar, bahkan membacanya belum sampai hatam. Ini artinya filter di beberapa lembaga pendidikan Islam masih belum bagus, dah perlu untuk ditingkatkan lagi.

\section{Ekstrekurikuler}

Kegiatan ekstrakurikuler juga menjadi salah satu faktor masuknya paham radikal pada peserta didik.Ekstrakurikuler ini berupa kegiatan Rohis di lembaga pendidikan Islam, yang sangat membantu para peserta didik lain dalam memahami agama Islam. Anggota Rohis tidak semua mendalami agama Islam dengan merujuk pada sumber-sumber yang valid, tetapi banyak juga yang mengandalkan internet. Belajar melalui berbagai sumber memang bagus, tetapi yang menghawatirkan ialah jika situs-situs yang dikunjunginya berupa situs dari kelompok radikal yang berisi kebencian, kecuriagaan, dan kekerasan. Tanpa sadar mereka terprovokasi oleh berbagai narasi yang dituliskan di situs-situs kelompok radikal. Diskusi dengan para kiai, ustadz, dan guru pun belum intens dalam membahas sebuah persoalan.

Wahid Foundation menyatakan bahwa radikalisme dapat tumbuh dari kegiatan Kerohanian Islam. Dari survei yang dilakukan Wahid Foundation pada 1.626 responden menyatakan bahwa $60 \%$ aktivis rohis siap melaksanakan jihad di wilayah yang saat ini konflik dan $68 \%$ siap jihad di masa mendatang. Kemudian dari jumlah responden juga didapatkan hasil $37 \%$ sangat menyetujui dan $41 \%$ setuju bahwa Indonesia menjadi negara Islam, dengan membentuk sistem khalifah. ${ }^{9}$ Dari hasil tersebut, maka aktivis rohis ini dapat pula menjadi faktor menguatnya radikalisme di lembaga pendidikan Islam.

\section{Faktor Eksternal}

Dalam sejarahnya, kelompok khawarij menjadi percontohan gerakan radikalisme yang ingin menerapkan sistem sesuai keyakinannya pada masyarakat. Mereka tidak menerima keputusan arbitrase dalam

${ }^{9}$ https://nasional.tempo.co/read/847299/w ahid-foundation-lebih-60-persen-aktivis-rohissiap-jihad 
menyelesaikan peperangan antara kelompok Alibin Abi Thalibdan Muawiyah dengan cara keluar dari barisan sahabat Ali bin Abi Thalib, kemudian membuat kelompok sendiri. Dengan kelompok ini, mereka melakukan berbagai gerakan untuk memerangi orang-orang yang dianggapnya salah, dengan mengafirkan dan mengklaim murtad muslim lainnya. Kaum ini memandang bahwa orang lain yang tidak mau menerima pandangannya dianggap sebagai musyrik. ${ }^{10}$

Mereka menginginkan penerapan konsep yang disusunnya berdasarkan visinya mengenai masyarakat kharismatik yang secara ketat berlandaskan al-Qur'an dan Sunnah. Ketatnya penafsiran dan fanatisme dalam berpendapat, membuat mereka mengakui kebenaran hanya ada pada dirinya sendiri. Oleh karena itu, semua pandangan mereka harus diikuti oleh muslim lainnya.Pada tahap selanjutnya, kaum khawarij jauh berada di pinggiran atau berada di luar ortodoksi Islam, baik secara politik ataupun keagaman, hingga pada akhirnya menjadi gerakan yang radikal. ${ }^{11}$

Sedangkan di Indonesia, gerakan protes yang dilakukan pada zaman dulu meliputi enam gerakan, yaitu gerakan jagoan, gerakan anti Cina, gerakan anti tuan tanah, gerakan mistik, gerakan mesianistik, dan gerakan Islam abangan. Gerakan protes ini banyak dilakukan

\footnotetext{
${ }^{10}$ John L. Esposito, Unholy War, (Yogyakarta: LKiS, 2003), hlm. 52

${ }^{11}$ Ibid., hlm. 52-53
}

oleh masyarakat di pedesaan, khususnya petani, kemudian gerakan nasional pada abad 20 sudah pindah ke kota dan berubah bentuk menjadi voluntary association. $^{12}$ Gerakan-gerakan protes tersebut merupakan ungkapan kekecewaan terhadap orang-orang yang memiliki power kuat, yang kemudian berbagai tindakannya banyak merugikan orang lain.

Di era kontemporer ini, gerakan anti terhadap beberapa hal yang berkaitan dengan negara mulai menguat, dengan munculnya kelompok-kelompok yang mengusung ide radikalisme,dalam hal ini pengusung ide tersebebut dibagi menjadi dua kategori, yaitu pertama upaya menegakkan syariat Islam terdiri dari Jamaah Salafi, Front Pembela Islam, Front Pemuda Islam Surakarta, Komite Persiapan Penegakkan Syariat Islam. Kedua upaya mendirikan negara dan kekhalifahan Islam, yaituMajelis Mujahidin Indonesia, Darul Islam, dan Hizbut Tahrir Indonesia. ${ }^{13}$ Selain itu, gerakan lainnya terakomodir dalam oraganisasi Hizbullah, Barisan Bismillah, dan Gerakan Pemuda Ka'bah. ${ }^{14}$ Kelompok-kelompok tersebut ada dan mengusung radikalisme bukan secara tiba-tiba, tetapi ada faktor-faktor yang mendorongnya. Di antaranya ialah persoalan kemaksiatan yang tidak terlalu diperhatikan pemerintah, peminggiran

\footnotetext{
${ }^{12}$ Kuntowijoyo, Muslim tanpa Masjid, (Bandung: Mizan, 2001), hlm.57

13 Endang Turmudi dan Riza Sihbudi, Islam dan Radikalisme di Indonesia, (Jakarta: LIPI Press, 2005), hlm. 12

${ }^{14}$ Ibid., hlm. 186
} 
umat Islam, dan anggapan bahwa rendahnya aktualisasi ajaran Islam bagi masyarakat.

Gerakan-gerakan ini sangat mempengaruhi proses pendidikan di lembaga pendidikan Islam, karena mulai banyak pendidik dan peserta didik yang mendukung berbagai gerakan ini. Lembaga pendidikan dalam hal ini kurang menanggapi adanya pengaruh gerakan-gerakan tersebut, sehingga diskusi ataupun obrolan-obrolan untuk menyikapi hal tersebut belum terlaksana secara merata.Dengan demikian, maka tidak heran jika radikalisme rentan masuk dalam lembaga pendidikan Islam secara mudah.

\section{Perkembangan Teknologi dan Informasi}

Pembelajaran sejak zaman dulu hingga saat ini banyak mengalami perubahan, terutama pasca berkembangnya teknologi dan Informasi. Siapapun bisa belajar tidak hanya di ruang kelas, tetapi juga melalui internet yang serba mudah dan serba ada. Adanya internet ini kemudian banyak yang merubah sistem pembelajaran, dari tatap muka menjadi pembelajaran berbasis IT. Media pembelajarannya,teknik, dan metode semua berbasis IT, tanpa meninggalkan pembelajaran konvensional. Hal ini banyak membantu para pendidik dan peserta didik dalam memahami materi yang disampaikan.

Namun maraknya berita hoax dan situs-situs radikal, sedikit banyaknya mengarahkan siapapun pada jurang nestapa. Banyak orang-orang yang menerima informasi dari internet tanpa disaring terlebih dahulu, tetapi langsung mempercayainya bahkan langsung disebar ke berbagai media sosial.Hal inilah yang banyak membuat masyarakat Indonesia mudah terpengaruh oleh hasutan-hasutan kelompok radikal. Benih-benih radikalisme tersebar luas di internet dan berbagai media sosial, maka tidak heran jika banyak dari kalangan muda yang terpengaruh.

Padahal seharusnya dalam membaca informasi harus dari situs-situs yang valid dan terpercaya. Jika membaca informasi dari situs lain, maka hal yang harus dilalukan adalah cerdas untuk menyeleksi informasi, dengan cara meneliti dulu background dari situs tersebut. Kemudian meneliti tulisantulisannya diambil dari sumber-sumber terpercaya atau bahkan memuat ujaran kebencian atau tidak. Pada intinya, penelitian situs ini bisa merujuk pada metode penelitian yang telah diterapkan oleh ulama hadis ${ }^{15}$ Adapun landasan untuk menyeleksi ialah surat Al-Hujarat: yang artinya: Hai orang-orang yang beriman, jika datang kepadamu orang fasik membawa suatu berita, Maka periksalah dengan teliti agar kamu tidak menimpakan suatu musibah kepada suatu kaum tanpa mengetahui keadaannya yang menyebabkan kamu menyesal atas perbuatanmu itu. (QS. Al Hujarat: 49).

\footnotetext{
${ }^{15}$ https://jalandamai.org/cerdas-

menyeleksi-informasi.html, diakses pada 23 November 2017 pukul 12.30.
} 


\section{GERAKAN PENDIDIKAN \\ ISLAM \\ RADIKALISME}

Pengertian pendidikan dalam Islam menurut Hasan Langgulung dapat dilihat dari dua segi, yaitu dari segi individu dan dari segi masyarkat.Dari segi individu, pegertian pendidikan Islam adalah proses menemukan potensi (bakat dan minat) yang kuat dalam diri peserta didik dan mengembangkan potensipotensi yang ada di dalam diri manusia. ${ }^{16}$ Sedangkan dari sudut masyarakat, pendidikan Islam adalah usaha untuk mewariskan budaya atau menginternalisasikan nilai-nilai budaya dan agama ke dalam diri peserta didik. ${ }^{17}$ Pendidikan Islam dalam hal ini sangat memperhatikan dua hal yang saling berkaitan, yaitu potensi individu dan lingkungan tempat individu tersebut hidup.

Hasan Langgulung menilai bahwa proses mewariskan nilai-nilai dari generasi tua kepada generasi muda dalam memelihara identitas masyarakat adalah hal yang saat ini harus digalakkan. Pertimbangannya ialah bahwa jika umat terdahulu sangat menekankan kejujuran dalam berkatakata dan bertindak, maka umat di era kontemporer ini juga sangat

\footnotetext{
${ }^{16}$ Hasan Langgulung, Pendidikan Islam dalam Abad 21, (Jakarta: Penerbit PT. Pustaka Al-Husna Baru, 2004), hlm. 69

${ }^{17}$ Ibid., hlm. 75
}

membutuhkan kejujuran. ${ }^{18} \mathrm{Jika}$ umat terdahulu sangat menekankan berpikiran dan perbuatan yang moderat, toleran, multikultur, dan tidak fanatik, maka umat Islam di zaman sekarang juga demikian. Oleh karena itu nilai-nilai kejujuran, moderat, toleransi, dan multikultur yang ditekankan dalam agama dan dilakukan umat terdahulu perlu untuk diwariskan kepada generasi muda di era kontemporer ini.

Gagasan pendidikan Islam anti radikalisme ini penting, karena pendidikan Islam memiliki dua peluang, yaitu penyebar benih radikalisme dan penangkal radikalisme. berbagai penelitian mengenai radikalisme menunjukkan bahwa ada lembagalembaga pendidikan tertentu tertentu yang mengajarkan fundamentalisme dan radikalisme pada peserta didik. ${ }^{19}$ Jika yang dikuatkan adalah peluang yang pertama, maka lembaga pendidikan Islam menjadi alat mewariskan benihbenih radikalisme. Dalam hal ini, peluang kedualah yang harus diperkuat oleh seluruh lembaga pendidikan Islam.

Memperkuat lembaga pendidikan Islam dalam menangkal radikalisme, harus dilakukan melalui dua hal, yaitu memperkuat internal lembaga

18 Hasan Langgulung, Asas-Asas Pendidikan Islam, (Jakarta: Penerbit PT. Pustaka Al-Husna Baru, 2004), hlm. 354

19 Andik Wahyun Muqoyyidin, "Membangun Kesadaran Inklusif-Multikultural untuk Deradikalisasi", Jurnal Pendidikan Islam, (Yogyakarta: Fakultas Tarbiyah dan Keguruan UIN Sunan Kalijaga Yogyakarta, Vol. II, No. 1 Juni 2013), hlm. 133 
pendidikan Islam dan memperkuat faktor eksternal.Faktor internal menjadi faktor inti dari ketahanan lembaga pendidikan Islam, sedangkan faktor eksternal harus mendukung penuh lembaga pendidikan Islam. Internal lembaga pendidikan Islam masih banyak yang perlu dibenahi dan diperkuat, baik dalam segi manajemen, kebijakan, dan kerjasama dengan eksternal lembaga.

\section{Internal Lembaga Pendidikan Islam Membangun Kesadaran}

Kini pendidikan Islam dihadapkan pada tantangan radikalisme, yang ingin mengendalikan lembaga pendidikan Islam dan digunakan mewariskan doktrin-doktrinnya.Para akademisi dan praktisi pendidikan yang notebene memiliki daya pikir kritis, harus secara bersama berjuang untuk menghadapi tantangan tersebut. Hal pertama yang harus dikuatkan adalah kesadaran individu dan kesadaran bersama.Dalam menggagas pendidikan Islam yang anti radikalisme, para praktisi dan akademisi harus memiliki tiga kesadaran, yaitu kesadaran teologis yang berupa niat, kesadaran strategis sebagai motivasi agar selalu bekerja dengan sungguh-sungguh dan konsisten dalam jangka panjang, dan kesadaran operasional dalam arti ikhlas. ${ }^{20}$

Kesadaran memiliki posisi yang suci dalam pendidikan Islam, yaitusebagai kunci dalam mewariskan nilai-nilai agama dan budaya sekaligus merespon berbagai persoalan yang hlm. 45

${ }^{20}$ Kuntowijoyo, Muslim tanpa Masjid..., dihadapi oleh pendidikan Islam.Kesadaran akan melahirkan ekspresi-ekspresi bervariatif dari individu maupun kelompok untuk memperbarui konsep pendidikan Islam.Kesadaran teologis dapat diartikan bahwa agama Islam merupakan agama yang rahmatan lil'alamin,ini harus diyakini sebagai kebenaran yang abadi dan akan selalu membawa kemaslahatan bagi manusia.Agama yang rahmatan lil'alamin,bukanlah hal kosong tanpa makna, tetapi di dalamnya mengandung iman, ilmu, dan amal.Kemudian kesadaran strategis berusaha untuk bekerja bersungguh-sungguh berdasarkan nilai-nilai yang terkandung dalam agama islam. Lalunilai-nilai rahmatan lil'alamin direpresentasikan dalam pembaruan pendidikan Islam.

Berangkat dari kesadaran teologis, strategis, dan operasional berbasis Islam rahmatan lil'alamin tersebut, maka ada dua gagasan mengenai pendidikan Islam, yaitupertama mempertahankan konsep pendidikan Islam yang selama ini telah terlaksana, dan diperkaya dengan berbagai nilai-nilai luhur bangsa dan agama.Gagasan ini hanya menginfiltrasi nilai-nilai luhur bangsa dan agama dengan tanpa menghentikan penerapan konsep pendidikan Islam.Kedua, merekonstruksi konsep pendidikan Islam yang merepresentasikan nilai-nilai rahmatan lil'alamin dan memiliki ciri khasanti radikalisme. Gagasan kedua ini menyusun kembali konsep pendidikan Islam agar memiliki ciri khas 
tersendiriyangdapat intens menangkal radikalisme.

\section{Mengoptimalkan Pendidikan Islam}

Manajemen

Di antara faktor yang membuat radikalisme masuk ke dalam lembaga pendidikan Islam ialah kurangnya kontrol dari kepala sekolah, pendidik, dan peserta didik kepada siapapun yang ada di lembaga pendidikan. Itu artinya manajemen pendidikan Islam yang diterapkan belum maksimal, baik perencanaannya, pengorganisasian, pelaksanaan, dan kontrolnya, atau hanya sebagian saja yang tidak berjalan normal.Fungsi berbeda dijelaskan dalam literatur lain yaitu perencanaan, pengorganisasian, kepemimpinan, dan kontrol.Penerapan yang tidak maksimal dari keempat fungsi tersebut, tidak akan membawa hasil yang maksimal atau bahkan membuat lembaga pendidikan Islam terpuruk dalam kancah pendidikan nasional.

Manajemen pendidikan Islam dalam membendung radikalisme,harus direvitalisasi, dioptimalkan, dan diaktualisasisesuai dengan teori yang sudah dipelajari dari berbagai ahli.Optimalisasi manajemen ini harus dilakukan dalam beberapa hal, yaitu dalam organisasi lembaga pendidikan, kurikulum, pembelajaran, pendidik, peserta didik, pembiayaan, dan lingkungan lembaga pendidikan.Aktor utama dalam mengoptimalkan manajemen pendidikan ini ialah kepala sekolah dan kepala madrasah dengan didukung oleh anggota organisasi lembaga pendidikan. Kerjasama yang saling mendukung ini harus dilakukan secara kontinyu, ibaratkan dalam pertarungan di babak final.

Ketika mengoptimalkan manajemen pendidikan Islam, maka harus ada sifat pendidikan yang menjadi ciri dari pengoptimalan tersebut.Hasil dari pengoptimalan manajemen pendidikan Islam akan muncul sifat-sifat lembaga pendidikan yang beupa 1) setiap program yang disusun berprinsip pada panduan kompetensi kognitif, afektif, dan psikomotor memakai landasan akhlak yang terpuji. 2) diversifikasi program disesuaikan dengan kebutuhan masyarakat luas, yang mengorientasikan pada penampilan, tingkah laku peserta didik agar memiliki rasa bertanggung jawab terhadap Allah, keluarga, bangsa, dan lingkungannya. 3) membangun kerjasama dengan institiusi lain, sehingga akan muncul solidaritas antar institusi. $^{21}$

\section{Memperkuat Pemahaman Agama dan Pancasila}

Ketika manajemen pendidikan Islam sudah dipotimalkan, maka hal yang perlu dilakukan dalam membendung radikalisme ialah memperkuat pemahaman Agama danideologi Pancasila.Agama dan Pancasila bukanlah hal yang bertentangan, karena Pancasila disusun berdasarkan nilai-nilai agama dan nilainilai lokal Indonesia. Pemahaman agama dipercaya dapat memberikan pengaruh

${ }^{21}$ Ramayulis, Ilmu Pendidikan Islam, (Jakarta: Kalam Mulia, 2013), hlm.373-374 
yang besar terhadap berpikir, bersikap, dan bertindak dalam kebhinnekaan di Indonesia. Agama menjadi dasar kehidupanumat Islam di Indonesia yang sudah paten dan tidak bisa ditawar lagi. Maka di lembaga pendidikan Islam sangat ditekankan kedalaman pemahaman agama, sebagai bekal beribadah dan bersosial.

Memperkuat pemahaman agama ini sebagai respon terhadap kelompok radikal yang bercirikhas lemah dalam memahami hakikat agama Islam. Pengetahuan yang setangah-setengah dapat membuat seseorang merasa berpengetahuan sempurna, padahal masih banyak hal-hal yang belum diketahunya. Pemahaman yang sepotong-sepotong ini menimbulkan pemahaman yang parsial, karena keterkaitan ayat satu dengan yang lainnya tidak diperhatikan.Kemudian hal tersebut akan menggerus esensi dari ajaran agama sendiri. ${ }^{22}$ Merasa sudah tahu dan sudah benar mengarahkanmereka berani bertindak dengan radikal. Hal inilah yang seringkali ditemukan dalam kasus-kasus kelompok radikal di mancanegara.

Selain itu, pemaknaan terhadap Pancasila juga perlu dikuatkan dan diarahkan pada hal yang positif, jangan sampai klaim kafir terhadap Pancasila merebak di Indonesia. Pancasila yang terdiri dari lima sila, merupakan manifestasi dari nilai-nilai agama dan nilai-nilai lokal Indonesia. Sebagai intisari dari nilai-nilai agama dan nilainilai luhur, maka kedudukan Pancasila di Indonesia ialah sebagai 1) pandangan hidup bangsa, 2) dasar negara, 3) ideologi bangsa dan negara. ${ }^{23}$ Ketiga kedudukan tersebut menunjukkan bahwa Pancasila memiliki posisi yang urgen di Indoesia, maka semua masyarakat Indonesia harus memahami makna dari Pancasila ini dengan benar.

Oleh karenanya, parapendidik dan orang-orang yang berkecimpung dalam lembaga pendidikan, perlu mengembangkn kompetensinya untuk memperkuat pemahaman tentang agama Islam dan Pancasila.Bagi pendidik, memperdalam pemahaman agama melalui pengajian, dialog, dan membaca buku-buku agama yang berciri khas moderat. Pemahaman agama bagi peserta didik di lembaga pendidikan Islam bisa diperkuat melalui pelajaran pendidikan agama Islam dan dibantu oleh para pendidik lainnya agar setiap pelajaran dikaitkan dengan ajaran Islam yang hakiki. Kemudian Pancasila juga harus diperkuat melalui akulturasi nilainilai Pancasila pada setiap mata pelajaran yang ada. Dengan pemahamaman yang kukuh, maka pendidik dan peserta didik dapat menghadapi dan meminimalisir gempuran gerakan radikalisme yang berusahan manyusup di lembaga pendidikan Islam.

${ }^{23}$ Kaelan, Pendidikan Pancasila, (Yogyakarta: Paradigma, 2010), hlm. 107-122 


\section{MengimplementasikanPendidikan Islam Berwawasan Multikultural}

Pengoptimalan

manajamen

pendidikan Islam akan mempersempit ruang gerak kelompok radikal menyusup ke lembaga pendidikan Islam. Fungsi yang sudah dioptimalkan mulai perencanaan, pengorganisasian, pelaksanaan, dan pengendalian atau kontrol akan memperkokoh lembaga pendidikan Islam. Oleh karenanya lembaga pendidikan tidak perlu bersikap eksklusif, bahkan sebaliknya harusbersifat terbuka terhadap berbagai usul, saran, dan perbedaan dalam lingkup pendidikan ataupun yang lebih luas. Dalam membendung radikalisme, perlu landasan multikultural dalam lembaga pendidikan Islam untuk membangun kesadaran akan perbedaan dan penghormatan.

Prinsip-prinsip dari pendidikan Islam berwawasan multikultural terdiri dari beberapa hal, yaitu:pertama, kesadaran mengenai perbedaan kultur, agama, ras, dan golongan.Kedua, perbedaan adalah rahmat yang dapat memperkaya danmendinamiskan kebudayaan Islam. Ketiga, ketika mengetahui adanya perbedaan dalam khazanah Islam, maka umat muslim perlu memilih pendapat yang moderat dari berbagai pendapat yang ekstrem. Keempat, perlu menjauhi klaim kebenaran diri sendiri. Kelima, tolongmenolong terhadap persoalan yang telah disepakati banyak golongan.Keenam, menunjukkan sikap toleransi terhadap berbagai persoalan yang diperselisihkan oleh ulama. Ketujuh, menghormati terhadap pendapat orang lain dengan asas kesadaran bahwa mungkin kebenaran bisa muncul dari manapun dan dari siapapun. ${ }^{24}$

Multikulturalisme dalam pendidikan Islam dapat memunculkan sikap saling menghargai dan menghormati. Dari prinsip-prinsip mengenai multikultural di atas, maka benih-benih radikalisme akan dapat dibendung dan digantikan dengan pemikiran yang multikultural.Ada tiga hal dalam memposisikan pendidikan Islam berwawasan multikultural di lembaga pendidikan Islam, yaitupendidikan berwawasan multikultural sebagai filsafat pendidikan, sebagai mata pelajaran atau kajian khusus, dan sebagai pendekatan dalam proses pendidikan.Dari ketiga hal ini, yang paling memungkinkan untuk diterapkan ialah multikultural sebagai pendekatan dalam pendidikan dan kajian.Sedangkan jika diimplementasikan sebagai filsafat pendidikan, maka itu akan lebih baik, karena pelaksanaan pendidikan sebagai pengembangan konsep multikultural. ${ }^{25}$

${ }^{24}$ Irwan Masduqi, "Deradikalisasi Pendidikan Islam Berbasis Khazanah Pesantren", Jurnal Pendidikan Islam, Fakultas Ilmu Tarbiyah dan Keguruan UIN Sunan Kalijaga Yoyakarta, Vol. II, No. 1, Juni 2013, hlm.8

25 Tatang M. Amirin, "Implementasi Pendekatan Pendidikan Multikultural Kontekstual Berbasis Kearifan Lokal di Indonesia", Jurnal Pembangunan Pendidikan: Fondasi dan Aplikasi, Vol. 1, No. 1, 2012,hlm. 6-7 


\section{Mengimplementasikan Pendidikan Islam yang Moderat dan Toleran Moderat}

Islam merupakan jalan tengah dalam berbagai hal, baik dalam hal konsep, perilaku, akidah, ibadah, dan hubungan sesama manusia. Sikap moderat merupakan salah satu ciri khas Islam dan merupakan salah satu tegakknya Islam di dunia. ${ }^{26}$ Sikap moderat artinya berada di tengah, tidak ekstrem kanan dan tidak ekstrem kiri, sehingga dengan sikap yang moderat ini akan dengan mudah untuk mengenali kelompok-kelompok yang ekstrem.Sikap moderat dalam Islam merujuk pada surat al-Baqarah ayat 143 yang artinya:Dan demikian (pula) kami telah menjadikan kamu (umat Islam), umat yang moderat agar kamu menjadi saksi atas (perbuatan) manusia dan agar Rasul (Muhammad) menjadi saksi atas (perbuatan) kamu.

Ummatan wasathaadalah kata kunci yang perlu diterapkan dalam lembaga pendidikan Islam. Moderat di lembaga pendidikan Islam bisa diimplementasikan dalam beberapa hal, yaitu 1) moderat dalam menentukan kebijakan, 2) moderat dalam menerapkan manajemen pendidikan Islam, 3) moderat dalam pembelajaran, 4) moderat dalam kurikulum pendidikan, 5)moderat dalam pembiayaan, dan 6) mendesain lingkungan yang moderat.Moderasi dalam beberapa hal ini perlu dilaksanakan sebagai upaya

\footnotetext{
${ }^{26}$ Yusuf Qhardhawi, Islam Ekstrem Analisis dan Pemecahannya..., hlm.16-17
}

menimbulkan kebiasaan yang moderat dalam berbagai hal. Harapannya ialah lembaga pendidikan tidak serta-merta menerima atau mengikuti pemahamanpemahaman yang radikal.

\section{Toleran}

Pengertian toleransi dijelaskan dalam diklarasi UNESCO saaat konferensi di Paris pada 25 Oktober-16 November 1996, bahwa toleransi adalah: "Rasa hormat penerimaan,dan apresiasi terhadap keragaman budaya dan ekspresi kita. Toleransi dapat terwujud jika didorong oleh pengetahuan, keterbukaan, komunikasi, hati nurani, kebebasan berfikir, dan kebebasan keyakinan. Toleransi adalah harmoni dalam perbedaan. Toleransi adalah sikap aktif yang mengakui hak asasi manusia universal dan kebebasan fundamental orang lain". ${ }^{27}$

Pendidikan Islam yang toleran dapat diimplementasikan pada sesama muslim dan non muslim,yang bertujuan untuk mendorong peserta didik agar bersedia menerima dan menghormati perbedaan pendapat dari luar pemahamannya.Pendidikan ini menekankan pada kontrol emosi diri dalam perbedaan, nilai-nilai kebijaksanaan da mewujudkan cinta kasih terhadap sesama manusia dalam bingkai Bhinneka Tunggal Ika.Bangsa Indonesia sangat menekankan implementasi toleransi dalam pendidikan Islam, pasalnya keragaman tanpa adanya

27 Irwan Masduqi, Berislam Secara Toleran, (Bandung, Mizan, 2011), hlm. 15 
toleransi akan membuahkan malapetaka yang hebat. ${ }^{28}$

Sekalipun toleran, namun pendidikan Islam tidak menghendaki peserta didik dan mahasiswa menjadi apatisdan mentolerir berbagai problem sosial.Toleransi dalam pendidikan Islam perlu dibangun di atas kebudayaan yang kritis, sehingga peserta didik dan mahasiswa dapat memberikan kiritik dan saran bagi siapapun yang melanggar kode etik sosial. Toleransi bukan semata-mata acuh terhadap berbagai macam problem sosial, namun harus tetap bertanggung jawab dalam mengontrol sosial. ${ }^{29}$ Mengormati, mengakui, serta dibarengi kontrol sosial terhadap perbedaan, dapat memberikan kestabilan dalam melaksanakan proses pembelajaran, sehingga dapat mempersempit ruang masuknyaradikalisme.

\section{EKSTERNAL LEMBAGA PENDIDIKAN ISLAM}

\section{Pemerintah Pusat dan Daerah}

Pemerintah di sini berperan mengatur pengelolaan lembaga pendidikan mengenai kurikulum, pedagogi, penilaian, pengembangan kompetensi pendidik, dan pemeliharaan sarana-prasarana. Pengaturan ini dilakukan melalui penerbitan kebijakan seperti undang-undang, peraturan

${ }^{28}$ Irwan Masduqi, "Deradikalisasi
Pendidikan Islam Berbasis Khazanah Pesantren",
Jurnal Pendidikan Islam, Fakultas Ilmu Tarbiyah
dan Keguruan UIN Sunan Kalijaga Yoyakarta,
Vol. II, No. 1, Juni 2013, hlm. 11-13
${ }^{29}$ Ibid., hlm. 15

pemerintah, dan surat edaran. Adapun fungsi kebijakan ini ialah 1) menyediakan akuntabilitas norma budaya yang diperlukan oleh lembaga pendidikan, 2) melembagakan mekanisme akuntabilitas dalam menukur dan mengontrol kinerja peserta didik dan pendidik. $^{30}$

Pemerintah dapat menerbitkan kebijakan-kebijakan untuk lembaga pendidikan dalam menangkal radikalisme. Kebijakan ini mutlak diperlukan untuk membangun dan memperkokoh ketahanan lembaga pendidikan, sehingga radikalisasi dapat dicegah secara sistematis.Adanya kebijakan anti radikalisme dari pemerintah, menunjukkan bahwa pemerintah sangat serius dalam menangani radikalisme di lembaga pendidikan. Keseriusan ini juga harus ditanggapi oleh lembaga pendidikan dengan mengimplementasikan berbagai kebijakan secara kontinyu dan sistematis.

\section{Peran Masyarakat}

Peran masyarakat dalam menangkal radikalisme akan terwujud secara sempurna dari masyarakat yang saleh. Masyarakat saleh ialah masyarakat yang percaya bahwa mereka memiliki risalah yang harus disampaikan kepada umat manusia dan dilestarikan bersamanya. Risalah tersebut ialah keadilan, kebenaran, dan kebaikan yang harus selalu diterapkan di sepanjang

30 Nanang Fattah, Analisis Kebijakan Pendidikan, (Bandung: PT. Remaja Rosdakarya, 2013), hlm. 132 
masa tanpa terpengaruh perubahan zaman. Masyarakat saleh bertugas sekuat tenaga dalam menyampaikanrisalahnya kepada manusia lainnya dan menerapkannya dalam kehidupan seharihari, tanpa batasan waktu dan tempat. ${ }^{31}$

Masyarakat dan lembaga pendidikan Islam memiliki relasi yang kuat, keduanya saling membutuhkan dan saling mendukung. Masyarakat juga bertanggung jawab jika terjadi dekadensi moral, pengelolaan tidak maksimal, dan terjadinya radikalisme di lembaga pendidikan Islam.Oleh karena itu, masyarakat perlu meyadari peran dan tanggung jawabnya terhadap perkembangan dan ketahanan lembaga pendidikan Islam di era kontemporer ini. masyarakat harus peduli dan mengulurkan tangan terhadap berbagai persoalan di lembaga pendidikan.Lembaga pendidikan akan menjadi lembaga yang tahan banting apabila sokongan masyarakatnya juga kuat, begitu juga sebaliknya.

Dalam hal iniperan masyarakat salehialah sebagai agen, yangselalu menebarkan pemahaman keagamaan dan kebangsaan mengenai keadilan, kebenaran, dan kebaikan, baik di lingkungan masyarakat sendiri maupun di lembaga pendidikan Islam. Masyarakat saleh akan menolong dan membina anggota masyarakat dan lembaga pendidikan Islam untuk membina hubungan-hibungan yang baik dan sesuai, kerjasama, besahabat, setia

\footnotetext{
${ }^{31}$ Hasan Langgulung, Pendidikan Islam dalam Abad 21 ..., hlm. 172
}

kawan, interdependen dan seimbang. ${ }^{32}$ Pembinaan terhadap relasi sosial dengan pihak-pihak lain, merupakan upaya untuk memperkuat kerjasama dan hubungan baik antar sesama lembaga pendidikan. Di samping itu, kontrol antar berbagai lembaga terhadap berbagai peserta didik juga dapat maksimal melalui relasi ini. ${ }^{33}$

\section{Partisipasi aktif masyarakat} secara resmi bisa melalui komite sekolah/madrasah, sedangkan di luar itu masyarakat dapat mengoptimalkan perannya melalui organisasi masyarakat seperti Muhammadiyah, Nahdlatul Ulama' ataupun organisasi dan komunitas-komunitas lainnya. Wadah dalam bentuk organisasi dan komunitas terssebutdapat membangun relasi dan dengan mudah melakukan gerakan pengawasan dan penguatan pada lembaga pendidikan Islam secara intens. Baik itu melalui pengajian-pengajian di masjid, mushola, TPQ maupunseminarseminar denganmengajarkan materimateri agama Islam dan nilai-nilai luhur bangsa.

Ormas-ormas yang sudah memiliki lembaga pendidikan formal sendiri, juga harus merangkul dan memaksimalkan peran serta masyarakat dalam mengokohkan lembaga pendidikan Islam. Ormas juga perlu

\footnotetext{
${ }^{32}$ Ibid.

${ }^{33}$ Hubungan kerjasama tidak hanya pengurusan proyak dan program yang incidental, tetapi program yang bisa terlaksana ialah kerjasama dalam saling mengawasi peserta didik atau mahasiswa. Kontrol semacam ini dapat menjad kontrol yang lebih maksimal.
} 
mengorganisir para wali murid khususnya dan masyarakat pada umumnya untuk meningkatkan kepedulian terhadap berbagai persoalan lembaga pendidikan Islam. Persoalan utama ialah membangunkepedulian terhadap persoalan radikalisme, masyarakat harus bergerak dalam sterilisasi dan membendung ancamanancama yang datang dari gerakan radikalisme.

\section{E. PENUTUP}

Lembaga pendidikan Islam sangat rentan dimasuki oleh radikalisme, pasalnya perhatian lembaga pendidikan terhadap pengaruh gerakan-gerakan ini masih minim. Tidak sedikit lembagalembaga pendidikan Islam tertentu yang belum memiliki ketahanan secara sistematis dalam menghadapi masif nya gerakan radikal ini. Radikalisme seolah tidak dianggap berkaitan dengan lembaga pendidikan Islam, keduanya seolah memiliki jalan sendiri yang tidak saling bersinggungan. Oleh karena itu, para pendidik minim kesadaran dan kurang mengembangkan kompetensinya. Kemudian kurang mengontrol peserta didik dan siapapun yang ada di lembaga pendidikan. Merebaknya berita-berita hoax dan situs-situs radikal banyak membuat siapapun di lembaga pendidikan terpengaruh. Gerakan radikal memanfaatkan internet untuk merekrut anggota-anggota baru melalui internet. Kemudian mereka sangat ingin menguasai lembaga pendidikan tertentu untuk menanamkan paham-pahamnya pada para peserta didik. Masifnya gerakan radikal ini seharusnya ditanggapi dengan serius oleh kepala sekolah dan pendidik-pendidiknya, agar radikalisme tidak secara mudah masuk ke lembaga pendidikan.

Ketika pendidikan anti radikalisme diterapkan dalam lembaga pendidikan Islam, maka lembaga pendidikan Islam dapat membendung paham-paham yang bersifat radikal.Dalam hal ini, sesuatu yang harus dilakukan adalah menyadari akan masifnya gerakan radikal di Indonesia, menerapkan dan mengoptimalkan manajemen pendidikan Islam, mengimplementasikan pendidikan Islam berwawasan multikultural, toleran, dan moderat. Dengan dukungan pemerintah dan masyarakat yang ada di sektiranya, maka lembaga pendidikan Islam bisa membendung gerakan radikalisme agar tidak leluasa masuk di lembaga pendidikan Islam.

\section{DAFTAR PUSTAKA}

Amirin, Tatang M., "Implementasi Pendekatan Pendidikan Multikultural Kontekstual Berbasis Kearifan Lokal di Indonesia", Jurnal Pembangunan Pendidikan: Fondasi dan Aplikasi, Universitas Negeri Yogyakarta, Vol. 1, No. 1, 2012.

Esposito, John L., Unholy War, Yogyakarta: LKiS, 2003.

Fattah, Nanang,Analisis Kebijakan Pendidikan, Bandung: PT. Remaja Rosdakarya, 2013. 
Kaelan, Pendidikan Pancasila, Yogyakarta: Paradigma, 2010.

Kuntowijoyo, Muslim tanpa Masjid, Bandung: Mizan, 2001.

Langgulung, Hasan,Pendidikan Islam dalam Abad 21, Jakarta: Penerbit PT. Pustaka Al-Husna Baru, 2004.

Pendidikan Islam, (Jakarta:

Penerbit PT. Pustaka Al-Husna Baru, 2004.

Masduqi, Irwan,Berislam Secara Toleran, Bandung, Mizan, 2011.

"Deradikalisasi

Pendidikan Islam Berbasis

Khazanah Pesantren", Jurnal

Pendidikan Islam, Fakultas Ilmu

Tarbiyah dan Keguruan UIN

Sunan Kalijaga Yoyakarta, Vol. II,

No. 1, Juni 2013.

Muqoyyidin, Andik Wahyun,

"Membangun Kesadaran Inklusif-

Multikultural untuk

Deradikalisasi”, Jurnal Pendidikan

Islam,Fakultas Tarbiyah dan

Keguruan UIN Sunan Kalijaga

Yogyakarta, Vol. II, No. 1 Juni 2013.

Nata, Abuddin,Filsafat Pendidikan

Islam, Jakarta: Gaya Media

Pratama, 2005.

Qhardhawi, Yusuf, Islam Ekstrem

Analisis dan

Pemecahannya,Bandung: Mizan, 1989.

Qodir, Zuly,Radikalisme Agama di

Indonesia, Yogyakarta: Pustaka

Pelajar, 2014.
Ramayulis, Ilmu Pendidikan Islam, Jakarta: Kalam Mulia, 2013.

Turmudi, Endang dan Riza Sihbudi, Islam dan Radikalisme di Indonesia, Jakarta: LIPI Press, 2005.

\section{Internet}

http://news.metrotvnews.com/peristiwa/ 4KZEoWpk-dunia-pendidikan-dinilairawan-disusupi-paham-radikalisme

https://nasional.tempo.co/read/1026907/ 3-tahun-jokowi-jk-akademikus-sorotimenguatnya-radikalisme

http://news.metrotvnews.com/hukum/Dk q62EeK-bnpt-riset-radikalisme-di-duniapendidikan

http://nasional.kompas.com/read/2017/0 5/02/15444221/radikalisme.menyusup.k e.dunia.pendidikan.ini.lima.modusnya.

http://www.iain-

samarinda.ac.id/index.php/2017/09/15/re ktor-iain-samarinda-paparkan-polapendidikan-anti-radikalisme-di-seminarinternasional/

https://nasional.tempo.co/read/847299/w ahid-foundation-lebih-60-persen-aktivisrohis-siap-jihad

https://jalandamai.org/cerdasmenyeleksi-informasi.html 